\title{
The importance of ethnicity as a risk factor for STDs and sexual behaviour among heterosexuals
}

\author{
C Hooykaas, F W van der Velde, M M D van der Linden`, G J J van Doornum, R A Coutinho
}

\begin{abstract}
Objectives-To study risk factors for sexually transmitted diseases (STDs) and sexual behaviour. Especially to assess whether there is a higher risk of being infected with STDs among ethnic minorities, and if so for what reasons.

Setting-STD-clinic of the Municipal Health Service of Amsterdam, the Netherlands.

Subjects-Cross-sectional study of heterosexuals (255 men and 343 women) with multiple sexual partners, who participated between October 1987 and January 1990.

Results-Besides STD-related complaints, ethnicity was an important independent predictor of one or more diagnosed genital STDs. STD-prevalence was higher among men born in Turkey $(47 \%, O R=3 \cdot 4)$ and men born in Surinam $(36 \%$, OR $=2 \cdot 1)$, compared with Dutch men $(21 \%)$. While Turkish men had mainly riskful sexual behaviour with prostitutes, Surinam men had more often riskful sexual contact with private partners. Among women, STD prevalence was higher among West-European (38\%, OR $=2 \cdot 3$ ) and LatinAmerican women $(30 \%$, OR $=1.6)$, compared with Dutch women (21\%). Latin American women had more often riskful sexual contact with clients; sexual behaviour of WestEuropean women was riskful with both clients and private partners.

Conclusions-Prevention activities should be directed at specific sexual and ethnic groups, sources of information should be carefully selected, and some groups should be addressed differently with regard to language but to content as well.
\end{abstract}

$\star$ Present affiliation is Sint Elisabeth Hospital, Clinic of Dermatology, Leiden, the Netherlands.

Municipal Health Service of Amsterdam, Department of Public Health, Amsterdam, The Netherlands

C Hooykaas, FW van der Velde, MMD van der Linden, GJJ van Doornum, RA Coutinho

\section{Introduction}

Despite the increase in knowledge about the causal agents, modes of transmission, diagnosis and therapy of sexually transmitted diseases (STDs), efforts have failed to curb the spread of STDs. Apparently, information campaigns and prevention activities, together with the existence of a network of STDclinics, only have a limited impact. ${ }^{12}$

Who are at risk for STDs? In the Western countries, recognised risk groups are homosexual men, prostitutes, clients of prostitutes and heterosexuals with multiple partners. More recently, heterosexuals from racial/ethnic minorities are recognised also to be at risk, especially with respect to infection with the human immunodeficiency virus (HIV). ${ }^{3-6}$ Campaigns targeted towards the prevention of AIDS and HIV-infection led to the adoption of safer sexual practices. This resulted in decreasing trends of certain STDs in the same period of time, especially among men with homosexual contacts and to a lesser extent among heterosexuals. ${ }^{6-8}$

However, limited information is available about the effectiveness of preventive efforts among ethnic minorities. To design prevention campaigns, it is essential to determine whether (and for what reasons) there is a higher risk of being infected with STDs among certain ethnic groups. In order to investigate this and other issues, a study among heterosexuals with multiple partners was conducted at one of the STD clinics of the Municipal Health Service of Amsterdam, the Netherlands.

Patients, data collection and methods

Patients and data collection

To study prevalence, incidence and risk factors of HIV infection and STDs, heterosexual visitors of one of the STD clinics of the Municipal Health Service of Amsterdam were asked to participate in this study if they had at least five different sexual partners in the preceding 6 months. Men with homosexual contacts, intravenous drug users and haemophiliacs were excluded from the study.

Approximately $50 \%$ of the eligible heterosexual STD clinic attenders participated in the study. Men not participating were younger, had less partners and had more often a non-Dutch nationality while the women had fewer partners than participating 
women. No differences were found in prevalence of STDs. ${ }^{9}$

Demographics and data concerning sexual behaviour were obtained using a standard questionnaire. Included, among others, were questions regarding (a) type and number of partners (that is, private and/or commercial), (b) frequency of vaginal intercourse and condom use and (c) history of STDs. Data regarding sexual behaviour were assessed covering a period of 4 months prior to entry into the study. All participants were physically examined for several STDs and treated if necessary, in accordance with the standard protocol of the STD clinic. Participants were asked to return every four months for follow-up study. This paper presents only data collected at entry of the study.

\section{STD diagnoses}

Direct microscopy was performed of material from urethra and/or cervix for gonorrhoea (men and women), and from the vagina for trichomonas. From all men and women, cultures were taken for gonorrhoea and Chlamydia trachomatis, and from women only also for trichomonas. For other STDs, such as genital herpes, material was taken when indicated.

Diagnostic criteria for gonorrhoea and Chlamydia trachomatis infection were a positive culture. Trichomoniasis was diagnosed by microscopy or culture. The diagnosis of syphilis was based on clinical examination, serology and dark-field microscopy. Diagnostic criteria of primary genital herpes were medical history, clinical examination and a positive culture. Condylomata acuminata diagnosis was based on medical history and clinical examination.

\section{Serological methods}

From all participants a blood sample was collected and analysed for antibodies to HIV (HTLV-III EIA and HIV1/HIV2 EIA, Abbott); borderline and reactive samples were confirmed with Western Blot (HIV-1, Du Pont). Screening for syphilis was performed using Treponema pallidum haemagglutination assay (TPHA, Fujirebio). Borderline and reactive samples were retested with the venereal disease research laboratory test (VDRL, Wellcome) and fluorescent treponemal antibody absorption test (FTA-abs, RIVM).

\section{Statistical methods}

To assess risk factors for diagnosed STDs, only those STDs were selected which are mainly transmitted through vaginal intercourse. Included were therefore lues recens, gonorrhoea. Chlamydia trachomatis, trichomoniasis, primary genital herpes and primary condylomata acuminata. Two participants were infected with HIV, and as it was impossible to establish when HIV was acquired, HIV infection was excluded as one of the genital STDs. Participants were split in a group without, and a group with one or more of these diagnosed genital STDs.

To estimate the number of unprotected vaginal contacts, the number of partners was multiplied by the relative frequency of vaginal intercourse and the relative frequency of condom use. This calculation was performed separately for private and commercial partners. Frequency scores for vaginal intercourse ranged from 0 (never) via $0.25,0.50,0.75$ to 1 (always), and for condom use on a comparable but reversed 5-point-scale from 1 (never) to 0 (always). For example, for a man with 6 sexual partners, who had vaginal intercourse often and used condoms half of the time, the estimated number of unprotected vaginal contacts is $6 \times 0.75 \times 0.50=2.25$. For arithmetic reasons, the number of private or commercial partners or unprotected contacts was set to 0 for those participants who had no such partners.

All analyses were performed separately for both sexes, using SPSS/PC.$+^{10}$ Distributions were analysed with the chi square test. Differences between means were assessed by analyses of variance, or when appropriate with t-tests for independent samples. To generate a model of risk factors for STDs, multiple logistic regression analysis with stepwise forward variable selection was used. Variables univariately significant and variables non-significant but otherwise considered important, were used in the logistic regression analyses. A two-sided confidence interval (CI) of $95 \%$ was used for all analyses.

\section{Results}

\section{General characteristics}

Between October 1987 and January 1990 (27 months of recruitment) 598 heterosexuals with five or more different partners in the 6 months preceding the study decided to participate: 255 men and 343 women. Women were somewhat younger than the men (mean age 28 vs 32 years). The majority of the women were born in the Netherlands (62\%), and this was true for only $49 \%$ of the men. Most women worked as prostitutes $(74 \%)$ and $87 \%$ had one or more private partners in the 4 months prior to the study. In the same period of time, $61 \%$ of the men visited prostitutes and $78 \%$ had private partners. One or more genital STDs were diagnosed in $81(24 \%)$ women and $70(27 \%)$ men (table 1$)$.

\section{Risk factors for STDs}

Men Some demographics and aspects of sexual behaviour of heterosexuals with and without diagnosed STDs are presented in table 2. Among men, demographic variables had stronger relations with STD prevalence than variables associated with sexual behaviour. Educational level was strongly associated with STD diagnoses, but also with country of birth $(p<0.001)$. Education ceased to be 
Table 1 Diagnosed STDs among heterosexual men and women with multiple partners by different ethnic group

\begin{tabular}{|c|c|c|c|c|}
\hline & \multicolumn{4}{|l|}{ Men born in } \\
\hline & $\begin{array}{l}\text { Netherlands } \\
n=124\end{array}$ & $\begin{array}{l}\text { Surinam/Antilles } \\
n=47\end{array}$ & $\begin{array}{l}\text { Turkey } \\
n=34\end{array}$ & $\begin{array}{l}\text { Other countries } \\
n=50\end{array}$ \\
\hline \multirow[t]{3}{*}{$\begin{array}{l}\text { Number diagnosed with } \\
\text { HIV infection } \\
\text { early syphilis } \\
\text { gonorrhoea } \\
\text { Chlamydia trachomatis infection } \\
\text { trichomoniasis } \\
\text { primary genital herpes } \\
\text { primary condylomata acuminata } \\
\text { Number }(\%) \text { with } \geqslant 1 \text { STD }\end{array}$} & $\begin{array}{r}0 \\
3 \\
6 \\
12 \\
1 \\
1 \\
5 \\
26(21 \%)\end{array}$ & $\begin{array}{l}0 \\
1 \\
10 \\
5 \\
1 \\
0 \\
0 \\
17(36 \%)\end{array}$ & $\begin{array}{l}0 \\
1 \\
7 \\
7 \\
1 \\
0 \\
0 \\
16(47 \%)\end{array}$ & $\begin{array}{l}1 \\
0 \\
6 \\
5 \\
2 \\
0 \\
0 \\
11(22 \%)\end{array}$ \\
\hline & \multicolumn{4}{|c|}{ Women born in } \\
\hline & $\begin{array}{l}\text { Netherlands } \\
n=214\end{array}$ & $\begin{array}{l}\text { Latin America } \\
n=44\end{array}$ & $\begin{array}{l}\text { West Europe } \\
n=32\end{array}$ & $\begin{array}{l}\text { Other countries } \\
n=53\end{array}$ \\
\hline $\begin{array}{l}\text { Number diagnosed with } \\
\text { HIV infection } \\
\text { early syphilis } \\
\text { gonorrhoea } \\
\text { Chlamydia trachomatis infection } \\
\text { trichomoniasis } \\
\text { primary genital herpes } \\
\text { primary condylomata acuminata } \\
\text { Number }(\%) \text { with } \geqslant 1 \text { STD* }\end{array}$ & $\begin{array}{r}0 \\
0 \\
4 \\
23 \\
17 \\
2 \\
5 \\
44(21 \%)\end{array}$ & $\begin{array}{l}0 \\
0 \\
3 \\
6 \\
3 \\
0 \\
2 \\
13(30 \%)\end{array}$ & $\begin{array}{l}1 \\
1 \\
1 \\
4 \\
6 \\
0 \\
2 \\
12(38 \%)\end{array}$ & $\begin{array}{l}0 \\
0 \\
1 \\
4 \\
5 \\
1 \\
1 \\
12(23 \%)\end{array}$ \\
\hline
\end{tabular}

^Included are all STDs presented in this table, except HIV-infection. Participants can be diagnosed with multiple STDs, so columns do not always add up to $100 \%$.

Table 2 Demographics, STD history, type and number of partners of heterosexual men $(n=255)$ and women ( $n=343)$ with multiple partners, according to STD diagnoses ${ }^{\star}$

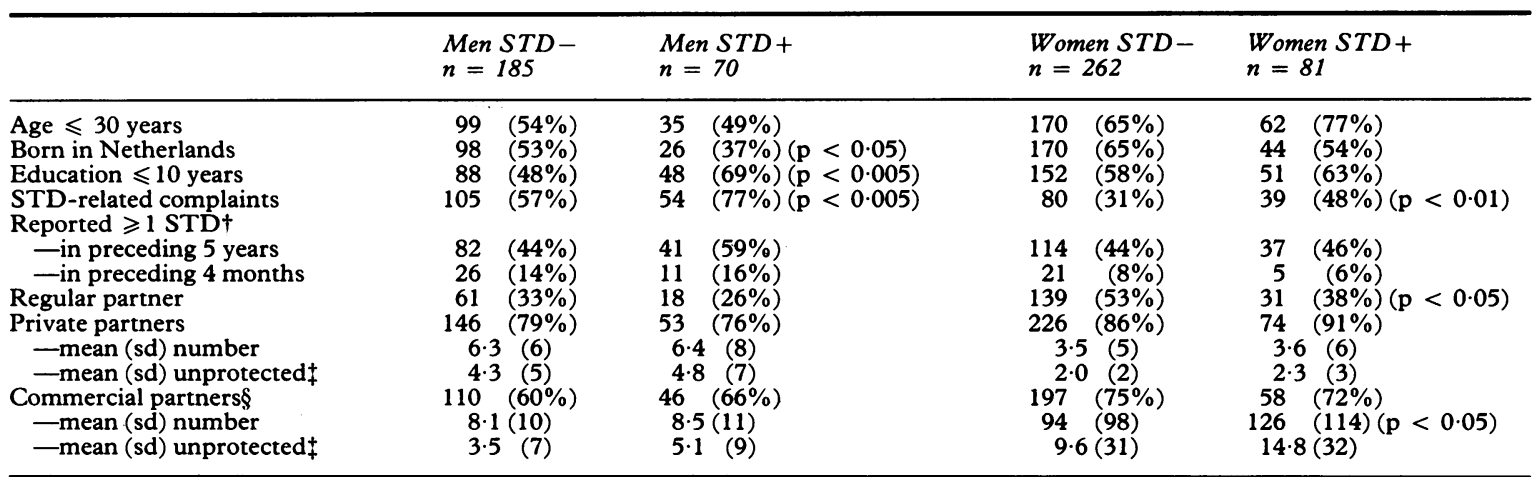

*As diagnosed STDs were included new infections with lues, gonorrhoea, Chlamydia trachomatis, trichomoniasis, genital herpes and condylomata acuminata. †As self-reported STDs were included lues, gonorrhoea, Chlamydia trachomatis and genital herpes. $\ddagger$ For calculation of unprotected vaginal contacts, see STATISTICAL METHODS. §The number of (unprotected) commercial partners of men (i.e. prostitutes) refer to the 4 months prior to study; the number of (unprotected) commercial partners of women (i.e. clients) refer to an average per month in 4 months preceding the study.

related with STD prevalence, when controlling for country of birth.

The independent variables included in the multiple logistic regression analyses are presented in table 2 . The only variables selected as risk factors in the multivariate analysis were whether men had STDrelated complaints and whether they were born outside the Netherlands. None of the variables concerning sexual behaviour were significantly related to STD diagnoses.

Country of birth was a strong predictor of STDs; therefore male participants were divided into three, socially meaningful, ethnic groups. Men were selected if they were born in (a) the Netherlands ( $\mathrm{n}=$ 124), (b) Surinam or the Dutch Antilles $(n=47)$ or (c) Turkey $(n=34)$. The remaining men were born 
Table 3 Risk factors for STD prevalence of heterosexual men $(n=205)$ and women ( $n=290)$ with multiple partners ${ }^{\star}$

\begin{tabular}{|c|c|c|c|}
\hline & $\begin{array}{l}\text { Odds } \\
\text { ratio }\end{array}$ & $\begin{array}{l}95 \% \\
\text { confidence } \\
\text { interval }\end{array}$ & pvalue $<$ \\
\hline \multicolumn{4}{|l|}{ Men } \\
\hline $\begin{array}{l}\text { STD-related complaints } \\
\text { Born in the Netherlands }\end{array}$ & $\begin{array}{l}2 \cdot 6 \\
1 \cdot 0\end{array}$ & $1 \cdot 8-3 \cdot 8$ & 0.01 \\
\hline Turkey & $4 \cdot 3$ & $2 \cdot 7-6 \cdot 8$ & 0.005 \\
\hline Surinam/Dutch Antilles & $2 \cdot 5$ & $1.7-3.7$ & 0.05 \\
\hline Age $>30$ years & $2 \cdot 1$ & $1.5-3.0$ & 0.05 \\
\hline \multicolumn{4}{|l|}{ Women } \\
\hline STD-related complaints & $2 \cdot 0$ & $1 \cdot 5-2 \cdot 6$ & 0.01 \\
\hline With regular partner & 0.45 & $0.34-0.60$ & 0.01 \\
\hline With private partners & $2 \cdot 7$ & $1 \cdot 7-4 \cdot 4$ & 0.05 \\
\hline
\end{tabular}

*Only men born in the Netherlands, Surinam/Dutch Antilles and Turkey were included; and women were included if they were born in the Netherlands, other West European countries and Latin-America.

in many different countries and constituted no homogenous group; they were excluded from further analyses. A repeated multiple logistic regression analysis in which country of birth was specified at three levels, revealed the risk factors shown in table 3. The same risk factors were selected, but age was included as an independent risk factor additionally. Again, no relation was found between sexual behaviour and having a STD. Univariate were Turkish men at highest risk for having a STD (Odds ratio $(O R)=3 \cdot 4,95 \% C I=2 \cdot 2-5 \cdot 0)$ and Surinam men at intermediate risk $(\mathrm{OR}=2 \cdot 1,95 \% \mathrm{CI}=1 \cdot 5$ 3.1), compared with Dutch men.

Women Only few variables of sexual behaviour were associated univariately with STDs (table 2). Independent risk factors for STDs generated with multiple logistic regression analysis were whether they had STD-related complaints, whether they were born outside the Netherlands, whether they had no regular partner and whether they had private partners. The type of partners (regular and private) were the only aspects of sexual behaviour associated with STD prevalence.

One of the selected risk factors was (as among men) country of birth. Therefore, women were divided also into three ethnic groups. They were selected if they were born in (a) the Netherlands ( $n=214)$, (b) other West European countries $(n=32)$ or (c) LatinAmerica $(n=44)$. The remaining women were excluded from further analyses. A repeated multiple logistic regression analysis with three levels of country of birth, revealed the risk factors shown in table 3. Except for country of birth, the same risk factors were selected. Although West-European women were univariately at highest risk $(\mathrm{OR}=2 \cdot 3,95 \%$ $\mathrm{CI}=1.6-3.5)$ and Latin American women at intermediate risk $(\mathrm{OR}=1 \cdot 6,95 \% \mathrm{CI}=1 \cdot 1-2 \cdot 3)$ com- pared with Dutch women, country of birth was not selected as risk factor in the multivariate analysis.

Factors related to sexual behaviour which may explain the higher STD prevalence in male and female non-Dutch participants, will be the focus of the remainder of this paper.

\section{Type of STD and STD history}

Men Prevalence of STDs was highest among Turkish $(47 \%)$, moderate among Surinam $(36 \%)$ and lowest among Dutch men $(21 \%, \mathrm{p}<0.005)$ (table 1). Compared with Dutch men, gonorrhoea was most often found among the Turkish and Surinam men $(\mathrm{p}<0.01)$. Chlamydia trachomatis was most often found among Turkish men, in contrast to Surinam and Dutch men (ns).

Dutch men reported less often than men from the other groups to have had one or more STDs in the preceding 5 years $(40 \%$ vs $63 \% ; \mathrm{p}<0.005)$ and in the preceding 4 months ( $10 \%$ vs $25 \%$; $<0.01$ ). No differences were found between Turkish and Surinam men. Although $77 \%$ of the Turkish men reported to have STD-related complaints, differences with the Surinam $(64 \%)$ or Dutch men $(61 \%)$ was not significant.

Women Dutch women differed from the other women only with respect to prevalence of diagnosed STDs $(21 \%$ vs $33 \%$; $<0.05)$. No other differences were found between the three groups. In contrast to men, only $2 \%$ of Dutch, $3 \%$ of West-European and $7 \%$ of Latin-American women were diagnosed with gonorrhoea. Prevalence of Chlamydia trachomatis was $11 \%, 13 \%$ and $14 \%$ respectively. The three distinguished groups did not differ in the history of STDs. STD-related complaints were reported by $21 \%$ of the Dutch, $30 \%$ of the Latin-American and $38 \%$ of the West-European women (ns).

\section{Sexual behaviour}

Men Dutch and Surinam men were more or less comparable, but contrasted with Turkish men with respect to the type and number of partners (table 4). Turkish men had private partners less often than the other men, and differed only from Surinam men with respect to the number of private partners $(p<0.01)$ and the number of unprotected private contacts $(p<0.05)$. Differences in the number of partners, rather than the small non-significant differences in condom use were reflected in the number of unprotected vaginal contacts with private partners.

On the other hand, Turkish men visited prostitutes more often $(p<0.001)$, visited more different prostitutes $(p<0.05)$, used condoms less frequently $(\mathrm{p}<0.05)$ and had more unprotected vaginal contacts with prostitutes $(p<0.05)$ than the other men. Contrary to sexual behaviour with private partners, differences in the number of unprotected vaginal contacts with prostitutes were influenced by differ- 
Table 4 Type and number of partners in 4 months preceding the study of 205 heterosexual men, according to ethnic group

\begin{tabular}{|c|c|c|c|c|}
\hline Men born in & $\begin{array}{l}\text { Netherlands } \\
n=124\end{array}$ & $\begin{array}{l}\text { Surinam } \\
n=47\end{array}$ & $\begin{array}{l}\text { Turkey } \\
n=34\end{array}$ & $\begin{array}{l}\text { Total } \\
n=205\end{array}$ \\
\hline Regular partner & $39 \quad(32 \%)$ & $17(36 \%)$ & $9 \quad(27 \%)$ & $65(32 \%)$ \\
\hline $\begin{array}{l}\text { Private partners } \\
\text {-number }(\%) \text { with } \\
\text { - mean (sd) } \\
\text { - mean (sd) unprotected\$̧ }\end{array}$ & $\begin{array}{l}104(84 \%) \\
6 \cdot 5(8) \\
4 \cdot 6(7)\end{array}$ & $\begin{array}{ll}39 & (83 \%) \\
7 \cdot 5 & (6) \\
5 \cdot 3 & (5)\end{array}$ & $\begin{array}{cl}19 & (56 \%) \\
3.6 & (3) \\
2.5 & (2)\end{array}$ & $\begin{array}{cl}162 & (79 \%) \ddagger \\
6.4 & (7) \\
4.5 & (6)\end{array}$ \\
\hline $\begin{array}{l}\text { Commercial partners } \\
\text { - number }(\%) \text { with } \\
\text {-mean (sd) } \\
\text { —mean (sd) unprotected } \$\end{array}$ & $\begin{array}{l}72(58 \%) \\
6 \cdot 5(6) \\
2 \cdot 7(5)\end{array}$ & $\begin{array}{ll}24 & (51 \%) \\
4 \cdot 1 & (4) \\
1 \cdot 5 & (3)\end{array}$ & $\begin{array}{l}32(94 \%) \\
11 \cdot 5(14) \\
6 \cdot 4(10)\end{array}$ & $\begin{array}{cl}128 & (62 \%) \ddagger \\
7 \cdot 3 & (9) \dagger \\
3 \cdot 4 & (7)^{\star}\end{array}$ \\
\hline
\end{tabular}

\$For calculation of unprotected vaginal contacts, see STATISTICAL METHODS.

${ }^{\star} \mathrm{p}<0.01 ; \mathrm{t} p<0.005 ;+\mathrm{p}<0.001$.

Table 5 Type and number of partners in 4 months preceding the study of 290 heterosexual women, according to ethnic group

\begin{tabular}{|c|c|c|c|c|}
\hline Women born in & $\begin{array}{l}\text { Netherlands } \\
n=214\end{array}$ & $\begin{array}{l}\text { Latin } \\
\text { America } \\
n=44\end{array}$ & $\begin{array}{l}\text { Western } \\
\text { Europe } \\
n=32\end{array}$ & $\begin{array}{l}\text { Total } \\
n=290\end{array}$ \\
\hline $\begin{array}{l}\text { Regular partner } \\
\text { Private partners }\end{array}$ & $102(48 \%)$ & $18 \quad(41 \%)$ & $15(47 \%)$ & $135(47 \%)$ \\
\hline $\begin{array}{l}\text { - number }(\%) \text { with } \\
\text {-mean (sd) } \\
\text { - mean (sd) unprotected } \$\end{array}$ & $\begin{array}{c}192(90 \%) \\
3 \cdot 5(4) \\
2 \cdot 2(3)\end{array}$ & $\begin{array}{cl}29 & (66 \%) \\
1 \cdot 7 & (2) \\
1 \cdot 1 & (1)\end{array}$ & $\begin{array}{l}31(97 \%) \\
5 \cdot 5(8) \\
3 \cdot 3(5)\end{array}$ & $\begin{array}{cl}252 & (97 \%) \ddagger \\
3 \cdot 5 & (5) \dagger \\
2 \cdot 2 & (3)^{\star}\end{array}$ \\
\hline $\begin{array}{l}\text { Commercial partners | } \\
\text { - number }(\%) \text { with } \\
\text { - mean (sd) } \\
\text { - mean (sd) unprotected§ }\end{array}$ & $\begin{array}{c}152(71 \%) \\
86(92) \\
4 \cdot 1(13)\end{array}$ & $\begin{aligned} 42 & (96 \%) \\
175 & (108) \\
44 & (61)\end{aligned}$ & $\begin{array}{cl}20 & (63 \%) \\
83 & (94) \\
7 \cdot 2(14)\end{array}$ & $\begin{array}{ll}214 & (74 \%) \ddagger \\
103 & (95) \ddagger \\
12 \cdot 3(30) \ddagger\end{array}$ \\
\hline
\end{tabular}

§For calculation of unprotected vaginal contacts, see STATISTICAL METHODS. |Number of clients per month, in 4 months preceding the study.

${ }^{\star} \mathrm{p}<0.05 ; \mathrm{t} \mathrm{p}<0.01 ; \neq \mathrm{p}<0.001$.

ences in both the number of prostitutes and frequency of condom use.

Women Sexual behaviour of Dutch and WestEuropean women contrasted with that of the LatinAmerican women (table 5). Latin-American women had private partners less often, and differed also in the number of these partners $(p<0.05)$ and in the number of unprotected vaginal contacts $(p<0.05)$. Like men, differences in the number of unprotected vaginal contacts with private partners were largely mediated by differences in the number of partners and less by differences in the low frequency of condom use.

Latin American women worked more often as prostitutes $(p<0.001)$, and had more clients per month $(p<0.001)$ than the other women. They usually worked "behind windows," while the other prostitutes had sexclubs more often as their worksite. Although $55 \%$ of the Latin-American prostitutes reported to use condoms always with clients, this was significantly less than the frequency of condom use of the other prostitutes $(76 \%, p<0.05)$. Combining the facts that (a) prostitutes working "behind windows" had more clients than those working in sexclubs (ca 50 vs ca 200 per month), (b) Latin American prostitutes worked mainly "behind wind- ows" and (c) used condoms relatively less often, this last group of prostitutes had unprotected vaginal contact with more clients than the other prostitutes $(<0.01)$.

\section{Discussion}

In our study, prevalence of one or more diagnosed STDs was most strongly predicted by the presence of STD-related complaints and of being other than of Dutch origin. While the first factor is comprehensible to explain STD prevalence, ethnicity per se is insufficient, especially when aspects of sexual behaviour instead of ethnic factors were expected to underlie the differences. Why was ethnicity such a powerful predictor, and apparently overruled the existing risk from sexual behaviour?

It is obvious from the results that the participants in all our ethnic groups had riskful sexual contacts, with either private and/or commercial partners. Besides differences in sexual behaviour, differences in STD prevalence among the ethnic groups may be explained by other aspects. The choice of partner within a group of a certain type of partner and higher prevalence rates of several STDs among specific communities can be underlying. ${ }^{11}$

Turkish men visited mainly prostitutes working 
"behind windows", and they also had the highest prevalence of gonorrhoea and chlamydia infection. Most of the Latin American prostitutes in our study worked "behind windows", and they also had the highest prevalence of gonococcal and chlamydial infections among women. Although we cannot determine exactly whether these mentioned groups are each others' commercial partners, these combined results suggest that riskful sexual contact within this type of setting more often leads to a STD.

The same reasoning can be applied to Surinam men and West-European women, with respect to their private partners. While the number of partners and frequency of condom use of these groups is comparable to Dutch participants, the higher prevalence of STDs may be explained by riskful sexual contact with persons from groups where these STDs are more prevalent.

We are aware that our results stem from a selected group of participants, and we should be careful to generalise from them. However, among the heterosexual visitors with multiple partners of the STD clinic who did not participate in our study, we found a comparable STD prevalence.' Another study among heterosexual STD-clinic attenders reported a decrease in the number of visitors since 1986 , which suggests a decrease in riskful sexual contact. Besides, a tendency towards safer sexual behaviour was found, but not among all heterosexual subgroups. Turkish men and prostitutes of other than Dutch origin appeared to be the exception. ${ }^{6}$ Even though these studies were conducted at the same STD clinics but with different objectives, the findings suggest that among sexually active heterosexuals, ethnic minorities are at an increased risk of contracting STDs.

In the last decade, much effort has been directed in the Netherlands to change attitudes and sexual behaviour of the general heterosexual population in the framework of STDs and in more recent years with respect to AIDS. These efforts did not result always in recommended safer sexual behaviour in all groups, as several studies reported. ${ }^{681213}$ Besides cultural differences, substantial language differences did exist also between the distinguished groups. It is not unlikely that the ethnic minorities therefore differ in access to sources of information, and have more difficulty than others in comprehending the messages about preventive measures to be taken.

Changes in prevalence and incidence of several STDs should be monitored closely with respect to different sexual and ethnic groups, to design continuously prevention activities focused on particular groups. Conveying messages to specific targetaudiences, sources of information should be carefully selected, and some groups should be addressed differently not only with regard to language but to content as well. While the prevention activities for STDs and HIV often are separated, integrating HIV as one of the STDs may lead also to a more coherent message and may be more effective. ${ }^{1415}$

We are grateful for the valuable assistance and cooperation of A $\mathrm{L}$ van Bolderik, $\mathrm{R}$ Wielings, $\mathrm{A}$ Thiele, S M G A van der Lans, J A P C M Kint, H M Pel and staff of the STD-clinic of the Municipal Health Service of Amsterdam, in conducting this study. We also thank J A R van den Hoek for her comments in preparing this manuscript.

This study was financially supported by a grant from the Dutch Foundation for Preventive Medicine, grant no 28-1529. ${ }^{12}$

Address of correspondence: Christa Hooykaas, MSc, Municipal Health Service of Amsterdam, Department of Public Health, room 416, Nieuwe Achtergracht 100, 1018 WT Amsterdam, the Netherlands.

1 Morton RS. Control of sexually transmitted diseases today and tomorrow. Genitourin Med 1987;63:202-9.

2 Fennema JSA, Hoek JAR van den, Rijsdijk AJ, Linden MMD van der, Coutinho RA. Het vóórkomen van seksueel overdraagbare aandoeningen bij bezoekers van twee geslachtsziekten poliklinieken in Amsterdam, 1981-1987. Ned Tijdschr Geneesk 1989;133:886-90.

3 Selik RM, Castro KG, Pappaioanou M. Racial/ethnic differences in the risk of AIDS in the United States. Am J Public Health 1988;78:1539-45.

4 Holmes KK, Karon JM, Kreiss J. Increasing frequency of heterosexually acquired AIDS in the United States, 1983-88. Am J Public Health 1990;80:858-63.

5 Lindan C, Kegeles S, Hearst N, Grant P, Johnson D. Heterosexual behaviors and factors that influence condom use among patients attending a sexually transmitted disease clinic-San Francisco. MMWR 1990;39:685-9.

6 Haastrecht HJA van, Hoek JAR van den, Coutinho RA. Evidence for a change in behaviour among heterosexuals in Amsterdam under the influence of AIDS. Genitourin Med 1991;67:in press.

7 Laar MJW van de, Pickering J, Hoek JAR van den, Griensven GJP van, Coutinho RA, Water HPA van de. Declining gonorrhoea rates in the Netherlands, 1976-88: consequences for the AIDS-epidemic. Genitourin Med 1990;66:148-55.

8 Hooykaas C, Linden MMD van der, Doornum GJJ van, Velde FW van der, Pligt J van der, Coutinho RA. Limited changes in sexual behaviour of hetersexual men and women with multiple partners in the Netherlands. AIDS Care 1991;3:21-30.

9 Linden MMD van der, Velde FW van der, Hooykaas C, Doornum GJJ van, Coutinho RA. HIV-prevalentie onder heteroseksuelen met veel wisselende partners in Amsterdam. Ned Tijdschr Geneesk 1990;134:1361-4.

10 Norusis MJ. SPSS/PC +V2.0 Base manual. Chicago: SPSS Inc, 1988.

11 Zimmerman HL, Potterat JL, Dukes RL, et al. Epidemiologic differences between chlamydia and gonorrhoea. Am J Public Health 1990;80:1338-42.

12 Hooykaas C, Pligt J van der, Doornum GJJ van, Linden MMD van der, Coutinho RA. Heterosexuals at risk for HIV: differences between private and commercial partners in sexual behaviour and condom use. AIDS 1989;3:525-32.

13 Sonnex C, Hart GJ, Williams P, Adler MW. Condom use by heterosexuals attending a department of GUM: attitudes and behaviour in the light of $\mathrm{HIV}$ infection. Genitourin Med 1989;65:248-51.

14 Pepsin J, Plummer FA, Brunham RC, et al. Interaction of HIV infection and other sexually transmitted diseases: an opportunity for intervention. AIDS 1989;3:3-9.

15 Marin G. AIDS prevention among Hispanics: needs, risk behaviours, and cultural values. Public Health Reports 1989;104:411-5.

Accepted for publication 1 August 1991 